Original research article

\title{
Barriers to assistance for women from marginalised Roma communities who are experiencing domestic violence
}

\author{
Ivan Rác \\ Constantine the Philosopher University in Nitra, Faculty of Social Sciences and Health Care, Institute of Romological Studies, Nitra, \\ Slovak Republic
}

\begin{abstract}
This paper deals with the issue of assistance for women from marginalised Roma communities who are experiencing domestic violence, which is a highly topical issue in the Slovak Republic. In the introduction, the paper focuses on clarifying the research problem, theoretical anchoring of the topic, and the research being carried out in this area. The more essential part includes the partial results of the longitudinal study on violence against Roma women (which started in 2016). The research objective was to identify the barriers to seeking assistance and the provision of this assistance for Roma women experiencing domestic violence. To achieve the research objective, the method of grounded theory (Strauss and Corbin version) was used. In the study, we conducted ten expert interviews with the representatives of selected organisations operating in Slovakia. They were the largest organisations operating in Slovakia. The analysis of the interviews showed that there are five main barriers to assistance for women from marginalised Roma communities who are experiencing domestic violence. These barriers are: prejudice and discrimination, downplaying and secondary victimisation by assisting professionals who are in first contact with the women experiencing the violence, unawareness of assistance opportunities among Roma women, inaccessibility of specialised services for victims of domestic violence, and, finally, multiple marginalisation of Roma women caused by poverty, community pressure, long-term unemployment, geographical isolation, and low standard of living. In the discussion section, the findings are compared with foreign findings by relevant authors.
\end{abstract}

Keywords: Accumulation of disadvantages; Domestic violence; Excluded communities; Roma women; Violence against women

\section{Introduction}

Domestic violence is a relatively recently researched phenomenon; therefore, there is considerable inconsistency in the terminology (Lober, 2005), definitions and approaches to its identification and effective elimination. In general, there are differences in the name given to the violence (Ferrer-Perez and Bosch-Fiol, 2014):

- by the crime scene (the criminological perspective): violence in family or domestic violence;

- by the victims, considering the family status and other specific characteristics (the perspective of helping professions): child abuse and neglect, partner abuse, abuse of the elderly, abuse of physically and/or mentally handicapped persons;

- specifying the victims by gender (the gender perspective): violence against women, violence against men.

The focus of this study is domestic violence against adult women which takes place in intimate relationships - wheth- er these are marital relationships or relationships without a formal contract of marriage. According to the WHO (2019), globally, up to $30 \%$ of women have experienced psychological and/or sexual violence.

According to the 2nd Representative Study on Violence Against Women in the Slovak Republic (Bodnárová et al., 2008; Oláh et al., 2012), violent behaviour has been experienced by every fifth adult woman with a partner; specifically $21.2 \%$ of adult women in the SR aged from 18 to 64 years. The prevalence of violent behaviour by former partners was even higher (27.9\%).

In violence against women, the World Health Organisation emphasizes the gender perspective. Violence against women is a violation of human rights, is rooted in gender inequality, is a public health problem, and an impediment to sustainable development (WHO, 2013; 2019). On the other hand, the WHO adopts multifactorial theories that are not based on one (central) cause of domestic violence. Instead they accept multiple risk factors, which, in interaction, can induce violent forms of behaviour in the home environment. The risk factors are listed in Table 1 (Krug et al., 2002).

\footnotetext{
* Corresponding author: Ivan Rác, Constantine the Philosopher University in Nitra, Faculty of Social Sciences and Health Care, Institute of Romological Studies, Kraskova 1, 94974 Nitra, Slovak Republic, e-mail: irac@ukf.sk http://doi.org/10.32725/kont.2020.042 
Table 1. Risk factors of violence against women (WHO, 2019)

\begin{tabular}{|c|c|c|c|}
\hline Individual & Interpersonal & Community & Societal \\
\hline $\begin{array}{l}\text { Childhood experience of } \\
\text { violence and/or exposure to } \\
\text { violence in the family. } \\
\text { Mental disorders. } \\
\text { Attitudes condoning or } \\
\text { justifying violence as } \\
\text { normal or acceptable. }\end{array}$ & $\begin{array}{l}\text { High levels of inequality in } \\
\text { relationships/male-controlled } \\
\text { relationships/ dependence on } \\
\text { partner. } \\
\text { Men's multiple sexual } \\
\text { relationships. } \\
\text { Men's use of drugs and harmful } \\
\text { use of alcohol. }\end{array}$ & $\begin{array}{l}\text { Harmful gender norms that uphold } \\
\text { male privilege and limit women's } \\
\text { autonomy. } \\
\text { High levels of poverty and } \\
\text { unemployment. } \\
\text { High rates of violence and crime. } \\
\text { Availability of drugs, alcohol and } \\
\text { weapons. }\end{array}$ & $\begin{array}{l}\text { Discriminatory laws on property ownership, } \\
\text { marriage, divorce and child custody. } \\
\text { Low levels of women's employment and } \\
\text { education. } \\
\text { Absence or lack of enforcement of laws } \\
\text { addressing violence against women. } \\
\text { Gender discrimination in institutions (e.g. } \\
\text { police, health). }\end{array}$ \\
\hline
\end{tabular}

Besides those stated by the WHO study, community factors may also include migration, nationality, and ethnicity (Tirone and Pedlar, 2005) - which maintains and transgenerationally transmits traditional gender stereotypes in communities. To a certain extent, they are separated from life and the rules of the majority society. In such cases, people face multiple disadvantages (Djikanovic et al., 2018).

The Roma are the largest ethnic group in Slovakia in which increased prevalence of violence against women in intimate relationships is presumed. According to the Atlas of Roma Communities (2019), in 2019 there were approximately 440,000 Roma identified in Slovakia (8.06\% of the population of Slovakia). In this case, this is attributed ethnicity - i.e. the persons are considered to be Roma by other people (Mušinka, 2019). Only a quarter of Roma state their origin as Roma; others state they are Slovak or Hungarian. In Slovakia, larger Roma communities live in 804 villages and towns, and smaller groups live in 373 other villages.

In Europe, the studies on the prevalence and particularities of domestic violence in Roma communities were, for example, conducted in Romania (Roth and Toma, 2014) and the neighbouring Czech Republic (Kajanová et al., 2015). In Slovakia, the qualitative studies on domestic violence against women were conducted by Rác (2015) and Rác et al. (2015). The study results suggest that the status of Roma women in Roma communities is lower than the status of men (Pivon and Stojka, 2003). Women must obey men; they learn these patterns of behaviour from their mother and father, where they have often seen how the stereotypical gender principle is applied - which also includes the violence of the father against the mother - so the woman may not realize that there is anything else than what she experiences (Rác, 2017). It also relates to her perception of violence or her tolerance limit. The woman may not identify the violence being done to her if she is physically or verbally attacked by her partner, but on the other hand, she may feel that what is happening to her is not right (Farkašová, 2015).

The social exclusion of Roma communities is linked to the low accessibility of information on violence (Yaman and Ayaz, 2010), i.e. unawareness of violence and its manifestations, or solutions to violence. If the woman knows that what is happening to her is not right and wants to solve her situation, she may not be able to get assistance due to the isolation of the community; thus she stays in the relationship and in the community (Thiara, 2002). In this context, it is a limited area in which there is low accessibility of information on violence; the pressure of the community as well as the pressure of the partner on the woman is very large; and the motivation of the woman to deal with her situation may be eliminated by the language barrier, or a lack of clarity of information on violence and accessible assistance and support, a lack of financial re- sources, and also distrust of the majority society or institutions (Rác et al., 2016).

In this paper, we state partial results of the longitudinal study on violence against Roma women which began in 2016. The study is divided into two basic parts. In the first part, the authors analysed the course and impact of violence against Roma women, where the research sample consisted of women from marginalised Roma communities. The second part of the study focused on the so-called helping professions, where the research sample consisted of the experts in the social area. In the paper we state the partial results of the second part of the study.

\section{Materials and methods}

The main objective of this study was to analyse the activities of selected organisations providing specialised assistance for Roma women experiencing violence. The partial objective, which is crucial for the topic of the paper, is to identify the barriers to seeking assistance and the provision of assistance for Roma women experiencing domestic violence. A basic methodological approach for the research data collection was a qualitative analysis of the statements (Švaříček and Šed'ová, 2007) by experts and field workers working in organisations providing specialised assistance for Roma women experiencing domestic violence. In the study, we used a semi-structured interview for empiric data collection. The sampling of participants was subject to two important criteria - the voluntary participation of experts in the study and direct experience of working with Roma women experiencing violence. In the study, we conducted ten expert interviews with the representatives of selected organisations operating in Slovakia. They were the largest organisations operating in Slovakia. Three organisations operate in the Bratislava Region, two organisations are in the Prešov Region and the Banská Bystrica Region, and one organisation is in the Nitra Region, the Košice Region and the Žilina Region. The sample consisted of field workers and other key informants whose job includes meeting Roma women who have experienced violence, and the experts working in crisis intervention services for assisting women experiencing violence or those who are at risk of violence. There were ten women; three women worked as field workers, two women were leaders in non-governmental organisations, and five participants worked as crisis intervention workers providing specialised counselling for women experiencing violence.

When conducting the interviews, we paid attention to the initial contact and the development of confidence. Prior to each interview there was a meeting in which the participants were informed about the study objectives and possible outcomes. 


\section{Results}

In the qualitative data collection, we collected a total of 684 minutes, i.e. more than 11 hours, of in-depth interviews, which transcribed to more than $140 \mathrm{~A} 4$ pages. In the data analysis, we used the so-called grounded theory method (Diagram 1). We identified a total of 80 codes, from which we subsequently generated categories and subcategories.

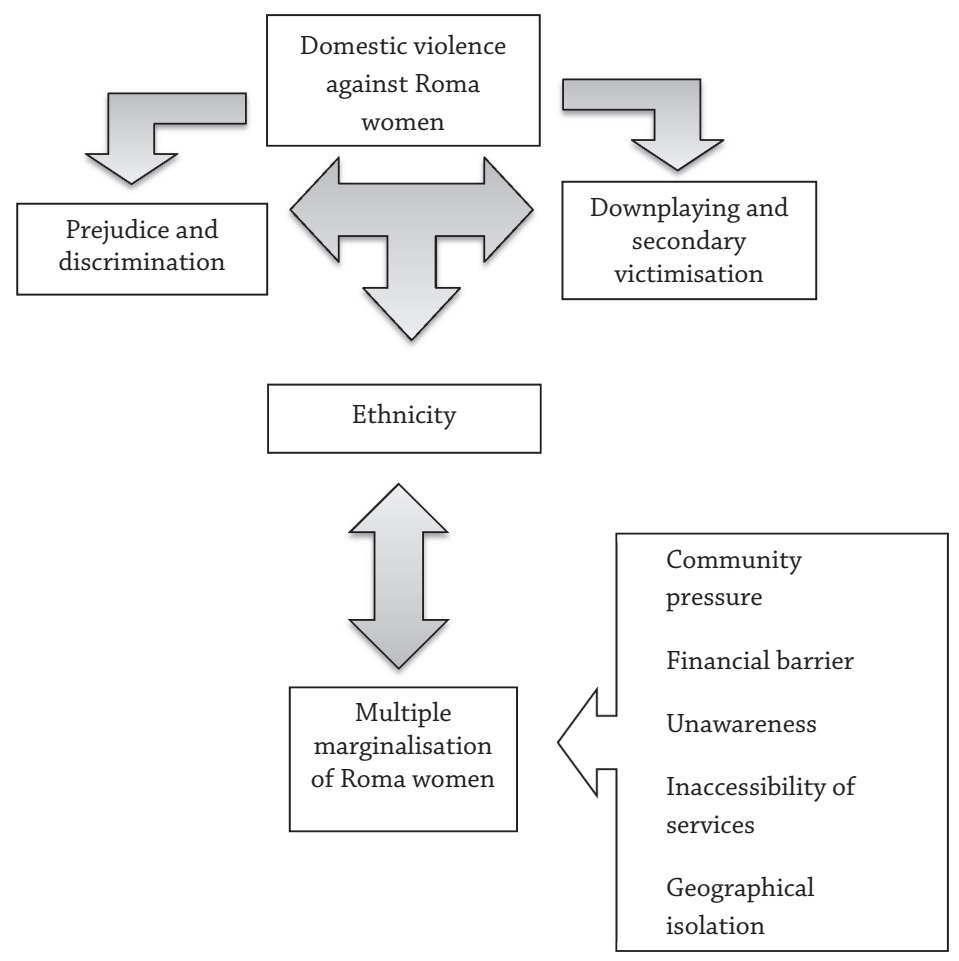

Diagram 1. Grounded theory (a methodology of the construction of a theory focused on action and interaction)

In relation to the so-called prejudices of the majority, we identified several statements by the participants on the basis of which we believe that Roma women stay in violent relationships.

\section{Prejudices and discrimination}

"In the same way we did not want to see wheelchair users in the past, now we act as if we do not want to see Roma people..." (Martina, Prešov).

"... that it is perceived just as a fact in those Roma women when she is not slapped twice, she is not even satisfied..." (Dana, Malacky).

In several cases, we came across a thesis that social facilities do not want to accommodate Roma women who experience violence, because, according to the statements of the directors of the accommodation facilities, "non-Roma" clients do not want Roma women to be accommodated there. In this case, it is an obvious discriminatory approach, which we interpreted by the subcategory discrimination (a behavioural level). Ethnicity, in the "conceptual model of barriers", identified as a context, played an extremely important role in providing potential assistance. As the selected interview transcripts show, it is not only her partner that treats here violently but also the institution/organisation refusing to provide her with crisis accommodation.

\section{Ethnicity}

"One of the first questions they asked in the accommodation facilities was: And is she a Roma? With the idea that we do not dis- criminate, but other women do not want to be accommodated with Roma women..." (Tatiana, Košice).

In this study, domestic violence against Roma women is perceived as a phenomenon that occurs in the environment of marginalised communities and, as in the majority society in Slovakia, it is indeed a major problem. It is important to say there is no representative study mapping the experiences of exclusively Roma women from marginalised communities. However, several qualitative studies have been conducted (See, for example, Rác et al., 2015; 2016) which point to the course and impact of violence against Roma women in intimate relationships.

In our study, the strategies for action in the present study show, in particular, downplaying by helping professions and secondary victimisation, which, as can be seen in the transcripts below, lead to an unprofessional approach by social workers in labour offices.

\section{Downplaying violence and secondary victimisation}

"With Roma clients, helping professionals quite commonly underplay and slightly disparage the issue of violence and they act as if all that is normal - that, after all, beating is usual among them" (Martina, Prešov).

Secondary victimisation is a consequence that may occur after the downplaying of violence, and also a process during which a woman experiences violence again and again. Thus, it is a violent process triggered by helping professionals' actions and behaviour which, for women, are more harmful than helpful. We identified this very important subcategory in several 
areas: in the action caused by the assistance system itself; in the action by social workers, professionals in non-governmental organisations; and by police officers.

"Often, it happened that a woman told us about the fact that the police only perceive it as a quarrel in the Roma settlement, that it is a daily routine, thus they do not believe what the woman tells the police at all - which results in the fact that the man who commits violence is absolutely unpunished" (Anna, Bratislava).

In the conceptual model of barriers to assistance for women from marginalised Roma communities experiencing violence, we consider the so-called multiple marginalisation of Roma women to be the consequence. We mean, in particular, the impossibility of many women to leave the relationship, in case they become "victims" of violence. I.e. they will remain in the relationship and, if they seek assistance, they are nevertheless disadvantaged several times over.

\section{Multiple marginalisation of Roma women}

"I think that, especially in case of violence, they are disadvantaged several times over, because they not only experience violence, which is the first discrimination, they are also disadvantaged in some sort of credibility, that often they are really looked down on. As if many such myths were associated with Roma women..." (Anna, Bratislava).

"If she is lucky, so it is fine, but if she is not lucky, she is indeed one of the last in this society" (Iveta, Michalovce).

In this study, pressure from within the community itself made it impossible for the victim to access relevant information on the available assistance, and maintained a violent relationship between the partners in the so-called public anonymity.

Thus, in the community, they could tell who was experiencing domestic violence, but they perceived it as something normal (Rác et al., 2016). The community in which Roma women live has a major influence on whether assistance is received or not. Many of them, under the influence of "community" pressure and prevailing gender prejudices and stereotypes, are not able to leave the environment they know, and leave their families, loved ones and relatives, even though they experience violence.

\section{Community pressure}

“... really everybody knows it, but no one will say anything and a person from outside, such as a field social worker or a mayor, has to intervene... because especially when they are clients that come from the settlements, they are really scared to leave their wellknown area... the settlements really differ from the areas of the majority society..." (Martina, Prešov).

We consider a lack of information among Roma women on the available assistance - and the inaccessibility of services provided for victims of violence in the region where they live to be an important intervening condition.

\section{Unawareness}

"... also in Slovakia, there are such abysmal differences, we really have regions, Banská Bystrica or Trenčín, where there are not many of those services and when a woman calls us from a smaller village in central Slovakia, so suddenly we have very limited possibilities for what we can recommend her, where we can send her" (Jana, Bratislava).

However, unawareness and related inaccessibility of services may not be interpreted only geographically. In some cases, Roma women's reasons for not seeking assistance are their fear of the majority society, lacking knowledge about the situation "out there in the faraway town", and lacking knowledge of the language, which all result in a lack of belief that anyone may help them at all.

\section{Geographical isolation}

"... they have a problem even to get, for example, to a town, for example to a district town, because they do not have money for travel fees... the second thing is also such a distrust of the majority society, that is, they are used to the fact that the majority society does not protect them nor cares about them, that is, that belief that they do not have help... they are even more convinced that if they do not help themselves somehow, the whites will not help them anyway" (Iveta, Michalovce).

Distrust is often accompanied by fear and feelings of shame, which, for women experiencing violence, is a typical feature in relation to not seeking assistance. This of course stems from the prevailing stereotypical perception of violence. The myths still exist that it is a "private thing", that it is a "family affair", and therefore many women stay in violent relationships.

The financial barrier, a significant intervening variable stemming from the economic dependence of Roma women on violent partners, is another reason for the inaccessibility of adequate assistance.

\section{Financial barrier}

"Not to mention the socio-economic issues; if a Roma woman decides to leave a violent relationship and, for example, she is on maternity leave, will she be able to find a job? Will she get a flat, I do not know, a council one? Where will she live? Where will she go?" (Tatiana, Košice).

\section{Discussion}

We learned (from the experts' statements about discrimination of Roma women) that it is their ethnicity which causes their difficulties in finding a job. In the case of a Roma woman who has more children, multiple disadvantages are manifested because she may not only have a problem finding a job, but also with finding suitable temporary accommodation (the experts came across the problem of the rejection of a Roma woman in a facility). Such multiple discrimination forces a woman to consider whether to leave a violent relationship, because in the relationship she is at least sure to have accommodation for herself and her children. Discrimination against Roma women is caused by a combination of inequalities resulting from gender, poverty, social exclusion, and inequality in communities (Frazer and Marlier, 2011). Roma women are still discriminated against in terms of equal access to work, education, housing, and health care (Cekota and Trentini, 2015; Mihalache and Rusanovschi, 2014; Morell, 2016; United Nations, 2006). The restriction of women's access to the labour market is influenced by the social inequalities that result from the nature of the patriarchal Roma family (Bogdanowicz-Gregorczyk and Caban, 2016; Merhaut, 2019). The traditional distribution of duties and household care gives men full power and is reflected in the societal order (Bordieu, 2001).

Downplaying the situation (due to a lack of information) significantly limits Roma women in getting professional assistance. A typical example is when a social worker (from a facility that should help women) perceived a Roma woman as someone who required violence from her partner. Secondary victimisation was also proved in the community - which hurts and denounces a woman if she decides to stand against a bully or to resolve the situation by filing a complaint. Excommu- 
nication of a Roma woman from the community may follow, which may lead to the fact that the woman - preventively to avoid exclusion - does not file a complaint, or, after leaving the community, returns to the bully. Finally, in this section, we heard an opinion about the diversity of communities and thus, depending on the extent of the community's communication with the majority, there is a greater or lesser degree of violence. If the community is in contact with the majority, violence can be more controlled; also, certain gender stereotypes (e.g. a woman must obey her man, as stated by one of the experts) may partially disappear, so in the end, the Roma woman gets help from her own family.

We agree with the findings of Sandberg (2013) and Teaster et al. (2006), who state that another problem women who experience violence face is the acceptance of violence as part of life, or even its toleration by the community. Certainly, this is not a sweeping generalisation; but is related to the persistent traditional way of thinking and a higher level of conservatism - which is also influenced by a different religious structure compared to the urban population. It is not rare if women experiencing violence in the communities are not understood (Sandberg 2013; Teaster et al., 2006).

Certain downplaying, or even tabooisation, of violence is stated also by Petrášová et al. (2015) and Tirone and Pedlar (2005); it is more typical for rural areas and accompanies higher levels of conservatism and the traditional perception of gender roles. There is a strong belief that family problems must be kept and tackled in a narrow family circle, and that it is not desirable for intimate affairs to be exposed publicly and discussed outside the family (Petrášová et al., 2015). We also acknowledge this statement in the present study; we interpreted strong community pressure as a major barrier to seeking assistance. Even if a Roma woman leaves a violent relationship, in many cases, the pressure does not have to be created by a violent partner but by her family, which makes her return to the community in which she either tries to deal with her situation, or she simply does not solve it, or she surrenders herself to a violent partner. The woman's isolation in the community directly depends on the degree of segregation and isolation of the place she lives in, which may reduce the accessibility of information on violence. Assistance is inaccessible for Roma women, and their chance to deal with the situation of violence is very low. Most communities are small in size and their members know each other. On the one hand, this evokes a higher level of social control and, in theory, also easier condemnation of the perpetrator's action as despicable, and an offer of help to a woman facing violence. On the other hand, more frequently, women fear that they may face defamation or criticism, which may prevent them from seeking assistance (Teaster et al., 2006).

However, one of the most serious problems of Roma women experiencing violence and living in excluded communities is geographical isolation. This is accompanied by multiple adverse facts such as a poorly developed or undeveloped network of social assistance facilities for women experiencing violence (Peek-Asa et al., 2011; Teaster et al., 2006; Thurston et al., 2006). A lack of services is significantly sharpened by the poorly developed infrastructure and problematic transport situation which significantly undercuts women's access to social assistance services (Peek-Asa et al., 2011; Teaster et al., 2006; Thurston et al., 2006). The geographical inaccessibility of some rural settlements also results in social isolation of women experiencing violence and easier concealment of violent behaviour (Peek-Asa et al., 2011; Peter and Drobnic, 2013). As stated by Teaster et al. (2006), such circumstances not only reduce the likelihood that the perpetrator's acts will be witnessed, but the attackers often use the isolation to take control of their victims. In relation to geographical isolation, we also identified unawareness of available assistance among Roma women and so-called white points of assistance in the form of inaccessibility of services as significant risks of potential violence. According to the foreign studies, many women are not aware of the existence of shelters for women experiencing violence.

In the analysis of the disadvantaged environment in relation to the issues of violence against women, the issues of unemployment or poverty and a low standard of living cannot be omitted. Several foreign studies also suggest that the deteriorated socio-economic situation is one of the defining characteristics of both the women experiencing violence and the perpetrators (Sandberg, 2013; Shuman et al., 2008). The poor financial situation keeps women experiencing violence in a partner-dependent situation and makes it impossible for them to seek and use (often paid) assistance services. The unfavourable financial situation is also a source of frequent partner conflicts that may result in violent behaviour. Men may perceive a loss of job as a personal failure. Therefore, they may behave violently in order to compensate for these feelings and stress (Petrášová et al., 2015).

In this study, we identified the stated topics with the term "multiple marginalisation of Roma women". This includes the economic dependency on a partner, in many cases a low level of education in women, their long-term unemployment, or the language barrier. According to the foreign studies, the women experiencing violence in such an environment (as well as the perpetrators of the violence) were characterised by a lower level of education. According to Rogers, a lower level of education, along with the poor economic situation, is also associatedwith the perceived lower ability to leave a violent relationship (Teaster et al., 2006). Women do not have the necessary skills or qualifications to become economically independent (Bartos, 2017). Roma women from marginalised communities have fewer opportunities to access formal employment due to inadequate education (Chichevaliev et al., 2016). As a result of the lower level of education, lack of skills, professional qualifications and employment opportunities, segregation, ethnicity and gender, Roma women from marginalised Roma communities are formally less employable than women from the majority society (Mihalache and Rusanovschi, 2014). Often, accumulated disadvantages cause women experiencing violence to become more and more anchored in their position, and limit their opportunities to escape the influence of a bully (who is usually an intimate partner or another close person).

\section{Conclusions}

If segregated and isolated from other parts of the town or village, the Roma community may have its own rules and customs according to which it functions. The life of Roma men and women in the excluded community is different to the majority. A Roma woman experiencing violence lives in a limited space whose characteristic feature is isolation. In this context, it is a limited area in which there is low accessibility of information about violence; the pressure of the community as well as the pressure of a partner on a woman is considerable; and the motivation of a woman to deal with her situation may be eliminated by the language barrier, a lack of clarity of information on violence and accessible assistance and support, a lack of financial resources, and also distrust of the majority society or institutions. 
In the interviews with the participants, we identified multiple barriers that a Roma woman must overcome if she wants to resolve her violent situation. These barriers often either discourage or prevent her from dealing with violence. The interpreted interviews suggest that if Roma women from marginalised communities are exposed to downplaying of violence, secondary victimisation, stereotypes about the perception of violence in communities and practical discrimination, they have a very small chance of leaving the vicious circle of violence. Sometimes an alarming situation in the Roma community in which violence against Roma women is committed could be solved by training or education for the public. This would demolish myths and misinformation, i.e. violence would prove to be a public - societal - issue, not a private - family issue. Thus, the false image of a Roma woman who requires violence, or an image of a community where violence is normal would be eliminated.
In the segregated Roma communities, violence is more pronounced due to the existence of poverty, persistence of strong gender ethnic stereotypes, isolation, or inadequate access to services. Roma women in segregated locations (characterised by isolation and persistence of strong gender ethnic stereotypes) have a special status within the society and family, as they are affected by multiple forms of marginalisation.

\section{Conflict of interests}

The author confirms that there is no conflict of interests in relation to this paper. This includes any financial, personal, or other relationships with people or organizations.

\section{Acknowledgements}

This paper was published as part of the project VEGA No. 1/0111/15: Violence Against Roma Women in Intimate Relationships.

\title{
Bariéry v pomoci ženám zažívajúcim domáce násilie z marginalizovaných rómskych komunít
}

\begin{abstract}
Súhrn
Predkladaný článok sa venuje problematike pomoci ženám zaživajúcim domáce násilie z marginalizovaných rómskych komunít, ktorá je v slovenských podmienkach vysoko aktuálnou témou. V úvode sa článok sústreduje na objasnenie výskumného problému, teoretické ukotvenie témy a výskumy, ktoré sa v tejto oblasti realizujú. Zásadnejšia čast' článku predstavuje parciálne čiastkové výsledky longitudinálneho výskumu násilia páchaného na rómskych ženách, ktorého realizácia začala v roku 2016. Výskumným ciel'om bolo identifikovat' bariéry pri vyhl'adávaní a poskytnutí pomoci, s ktorými sa stretávajú rómske ženy zažívajúce domáce násilie. Pre naplnenie výskumného ciel'a bola zvolená metóda zakotvenej teórie verzie podl'a autorov Strauss a Corbin. Vo výskume sme viedli 10 expertných rozhovorov so zástupkyňami vybraných organizácií pôsobiacich na území Slovenska. Išlo o najväčšie organizácie pôsobiace na území Slovenska. Analýza rozhovorov ukázala, že existuje pät hlavných bariér pomoci ženám zažívajúcim domáce násilie z marginalizovaných rómskych komunít, a to: predsudky a diskriminácia, bagatelizácia a sekundárna viktimizácia zo strany pomáhajúcich profesionálov, ktorí sú v prvom kontakte so ženami zažívajúcimi násilie, d’alej je to neinformovanost' samotných rómskych žien o možnostiach pomoci, nedostupnost́ špecializovaných služieb pre obete domáceho násilia a nakoniec viacnásobná marginalizácia rómskych žien spôsobená chudobou, tlakom zo strany komunity, dlhodobou nezamestnanostou, geografickou izolovanostou a nízkou životnou úrovňou. Výsledné zistenia sú v diskusii konfrontované so zahraničnými zisteniami relevantných autorov.
\end{abstract}

Kl'účové slová: domáce násilie; kumulácia znevýhodnení; násilie páchané na ženách; rómske ženy; vylúčené komunity

\section{References}

1. Bartos CHS (2017). Romani Women: The European Union's Most Stigmatized Minority. Claremont-UC Undergraduate Research Conference on the European Union 3(1): 43-52.

2. Bodnárová B, Filadelfiová J, Holubová B (2008). Reprezentatívny výskum výskytu a skúsenosti žien s násilím páchanom na ženách (VAW) na Slovensku [The Representative Research on Occurrence and Experiences of Women with Violence Against Women]. Bratislava: IVPR (Slovak).

3. Bogdanowicz-Gregorczyk J, Caban A (2016). Report on the situation of Roma women in Poland. Brusel: European Council.

4. Bordieu P (2001). Masculine Domination. Staford: Staford University Press.

5. Djikanovic B, Stamenkovic Ž, Bjegovic Mikanovic V, Vukovic D, Gordeev VS, Maksimovic N (2018). Negative attitudes related to violence against women: gender and ethnic differences among youth living in Serbia. Int J Public Health 63: 923-932. DOI: 10.1007/s00038-017-1033-y.

6. Cekota J, Trentini C (2015). Romania: Increasing Gaps and Policy Challenges. European-Asia Studies. Identities 67(4): 12-19.

7. Chichevaliev S, Jasharova S, et al. (2016). Roma Women Research: Macedonia. Madrid: Kamira Foundation and Skopje: LIL.
8. Farkašová M (2015). Romani Women in the 21st Century and the Role of their Position for Children's Upbringing. Journal of Gender and Power 3(1): 163-171.

9. Ferrer-Perez VA, Bosch-Fiol E (2014). Gender violence as a social problem in Spain: Attitudes and acceptability. Sex Roles 70: 506-521.

10. Frazer H, Marlier E (2011). Promoting the Social Inclusion of Roma. Galway: National University Ireland.

11. Kajanová A, et al. (2015). Nerovnosti v romských rodinách [Inequalities in Roma Families]. Praha: NLN (Czech).

12. Krug E, et al. (2002). World Report on Violence on Health. Geneva: WHO.

13. Lober J (2005). Gender inequality: Feminist theories and politics. New York, NY: Roxbury Publishing.

14. Merhaut M (2019). Theoretical studies focused on gender discrimination against roma women in the Czech Republic. Journal of Ethnic and Cultural Studies 6(1): 21-30. DOI: $10.29333 /$ ejecs/147.

15. Mihalache I, Rusanovschi S (2014). Study on the Situacton of Romani Women and Girls in the Republic of Moldova: Kišiňov: UN Women.

16. Morell IA (2016). Roma women's marginalities in the recognition struggles of a Hungarian Roma Women's NGO. Journal of Gender and Feminist Studies 7(21): 68-77.

17. Mušinka A (2019). Methodology of three statistical surveys (so called Atlas) of Roma communities in Slovakia and political 
representation of Roma in settlements of Prešov Self-governing Region. Annales Scientia Politica 8(2): 79-89.

18. Oláh M, et al. (2012). Metódy sociálnej práce v praxi [Social Work Methods in Practice]. Bratislava: VŠZaSP sv. Alžbety (Slovak).

19. Peek-Asa C, Harland KK, Beyer KMM, Wallis A (2011). Rural Disparity in Domestic Violence Prevalence and Access to Resources. J Women's Health 20(11): 48-55. DOI: 10.1089/ jwh.2011.2891.

20. Peter S, Drobnic S (2013). Women and their memberships: Gender gap in relational dimension of social inequality. Research in Social Stratification and Mobility 31: 32-48. DOI: 10.1016/j.rssm.2012.09.001.

21. Petrášová V, et al. (2015). Osobitné skupiny ohrozených žien násilím - ženy z vidieckeho prostredia [Specific Groups of Women at Risk of Violence - Women from Rural Areas]. Bratislava: IVPR (Slovak).

22. Pivoň R, Stojka P (2003). Náš život [Our Life]. Bratislava: InfoRoma (Slovak).

23. Rác I (2015). Násilie páchané na ženách v partnerskom vzt'ahu [Violence Against Women in an Intimate Relationship]. Nitra: UKF, 109 p. (Slovak).

24. Rác I (2017). Sociálne služby pre ženy zažívajúce násilie [Social Services for Women Experiencing Violence]. Nitra: UKF (Slovak).

25. Rác I, Dvončová N, Mirgová L, Oláhová M, Polakovičová B, Szapuová Ž, Tökölyová V (2015). Osobitné skupiny ohrozených žien násilím - rómske ženy [Specific Groups of Women at Risk of Violence - Roma Women]. Bratislava: IVPR (Slovak).

26. Rác I, Mátel A, Kozubík M (2016). Násilie páchané na rómskych ženách v partnerských vztahoch [Violence Against Roma Women in Intimate Relationships]. Sociální práce / sociálna práca 16(4): 62-77 (Slovak).

27. Roth M, Toma S (2014). The Plight of Romanian Social Protection: Addressing the Vulnerabilities and Well-being in Romanian Roma Families. The International Journal of Human Rights 18(6): 714-734. DOI: 10.1080/13642987.2014.944813.

28. Sandberg LJ (2013). Backward, Dumb, and Violent Hillbillies? Rural Geographies and Intersectional Studies on Intimate Partner Violence. Journal of Women and Social Work 28(4): 28-35. DOI: 10.1177/0886109913504153.
29. Shuman RD, Jr., McCauley J, Waltermaurer E, Roche WP, 3rd, Hollis H, Kilgannon Gibbons A, et al. (2008). Understanding Intimate Partner Violence Against Women in the Rural South. Violence and Victims 23(3): 390-405. DOI: 10.1891/08866708.23.3.390.

30. Švaříček R, Šed'ová K (2007). Kvalitativní výzkum v pedogogických vědách - pravidla hry [Qualitative Research in Pedagogical Sciences - Game Rules]. Praha: Portál, 384 p. (Czech).

31. Teaster PB, Roberto KA, Dugar TA (2006). Intimate Partner Violence of Rural Aging Women. Family Relations 55(5): 636-648. DOI: 10.1111/j.1741-3729.2006.00432.x.

32. The Atlas of Roma Communities in Slovakia [Atlas rómskych komunít na Slovensku] (2019). Bratislava: Úrad splnomocnenca vlády SR pre rómske komunity. [online] [2020-04-15]. Available from: http://www.minv.sk/?atlas-romskych-komunit-2019 (Slovak).

33. Thiara RK (2002). Domestic Violence and Women from Black and Minority Ethnic Communities: Some Issues and Implication for Domestic Violence Services. Fempower 6(3): 1-4.

34. Thurston WE, Patten S, Lagendyk, LE (2006). Prevalence of Violence Against Women Reported in a Rural Health Region. Can J Rural Med 11(4): 23-29.

35. Tirone S, Pedlar A (2005). Leisure, Place, and Diversity: The Experiences of Ethnic Minority Youth. Canadian Ethnic Studies 37(2): 32-48.

36. United Nations (2006). Report of the Committee on the Elimination of Discrimination against Women. New York: United Nations.

37. WHO (2013). Global and Regional Estimates of Violence Against Women: Prevalence and Health Effects of Intimate Partner Violence and Non-Partner Sexual Violence.

38. WHO (2019). Preventing violence against women. [online] [2020-03-13]. Available from: https://apps.who.int/iris/ bitstream/handle/10665/312261/WHO-RHR-18.19-eng. pdf?ua=1

39. Yaman S, Ayaz, S (2010). Domestic violence against women and women's opinions related to domestic violence. Anadolu Psikiyatri Dergisi/Anatolian Journal of Psychiatry 11: 23-29. 